\title{
Sonographic Appearance of Abdominal Wall at the Left Flank of Laparotomy Incision Site in Ettawah Grade Does
}

\author{
M. F. Ulum ${ }^{a}$, , D. R. Setiadia , B. Panjaitan ${ }^{b}$, M. Noordin ${ }^{a}$, \& Amrozi ${ }^{a}$ \\ ${ }^{a}$ Division of Veterinary Reproduction, Obstetrics and Gynecology, Department of Veterinary Clinic Reproduction \\ and Pathology, Faculty of Veterinary Medicine, Bogor Agricultural University \\ Jln. Agatis Kampus IPB Dramaga, Bogor 16680, Indonesia \\ ${ }^{b}$ Laboratory Clinics, Faculty of Veterinary Medicine, Syiah Kuala University \\ Jln. Tgk. Hasan Krueng Kalee No. 4, Darussalam, Banda Aceh 23111, Indonesia \\ (Received 19-06-2014; Reviewed 07-08-2014; Accepted 08-09-2014)
}

\begin{abstract}
The aim of this study was to describe the sonographic appearance of abdominal wall at the left flank of laparotomy incision site in 11 mated Ettawah grade does. Brightness-mode ultrasound examination by using transducer with frequency of 5.0-6.0 MHz was conducted to grouping the does based on their pregnancy statuses. The incision site of the abdominal wall at left flank laparotomy was transcutaneous-scanned as long as $8 \mathrm{~cm}$ vertically. The sonographic appearance of the laparotomy wall thickness showed that in all groups of does were similar and not different statistically. The thickness of oblique external and oblique internal abdominal muscles increased in the pregnant does as compared to non-pregnant does $(P<0.05)$.
\end{abstract}

Key words: laparotomy, left flank, ultrasonography, incision site, Ettawah grade does

\section{ABSTRAK}

Penelitian ini bertujuan untuk mencitrakan daerah sayatan laparotomi pada legok lapar kiri dari 11 ekor kambing peranakan Ettawah betina yang telah dikawinkan. Ultrasonografi dengan transduser 5,0-6,0 MHz digunakan untuk mengelompokkan kambing berdasarkan status kebuntingan. Daerah laparotomi dinding perut bagian legok lapar kiri dicitrakan secara transkutaneus sepanjang 8 $\mathrm{cm}$ pada daerah orientasi sayatan. Citra ultrasonografi daerah sayatan laparotomi dinding perut bagian legok lapar kiri dari semua kelompok tidak berbeda. Terjadi peningkatan ukuran ketebalan pada otot abdominalis eskternal dan internal pada kelompok kambing dengan status bunting jika dibandingkan dengan yang tidak bunting $(P<0,05)$.

Kata kunci: laparotomi, legok lapar, ultrasonografi, daerah sayatan, kambing peranakan Ettawah

\section{INTRODUCTION}

Laparotomy is a surgical procedure that incise the abdomen wall to access into abdominal cavity (Mann et al., 2011). Laparotomy in animals should be conducted aseptically (Bedard et al., 2001) and legeartically (Bourel et al., 2013) in several parts of the abdomen according to the surgical indication. Indication of surgical procedure to handle the difficulty in parturition (dystocia) in ruminants is usually conducted in the site of left flank of laparotomy (Bienek \& Grunert, 1997; Seger et al., 1994; Mee, 2008). The incision site in the left flank of laparotomy wall by ultrasound imaging consisted of skin, subcutaneous tissue and fat (adipose), oblique

\footnotetext{
*Corresponding author:

E-mail: ulum@ipb.ac.id
}

external abdominal muscle, oblique internal abdominal muscle, transversal abdominal muscle, and peritoneum (Buczinski et al., 2010). Laparotomy surgical procedure would incise the abdominal muscle layers one by one to access the abdomen cavity and finally to reach the fetus in caesarian section.

Ettawah grade goat is one of small ruminant animals diversified for milk production that is adapted to various feed resources in Indonesia (Novita et al. 2006). This breed of goat is popular in the farmer due to its good production and reproduction characteristics as a milk-producing goat (Sukendar et al., 2005). One of medical consequences for milk-producing animals is the difficulty in calving or kidding (Wehrend et al., 2006; Tenhagen et al., 2007). Dairy cows frequently experience problem and difficulty in calving due to the incompatibility between the fetal size and the maternal posture (Mee, 2008). 
Ultrasonography is one of sound energy-based technologies that is used as a supporting diagnostic tools (Noviana et al., 2012). Ultrasonography capable of imaging all soft tissues in the body to show the internal architecture of the examined tissue or organs. Ultrasonography imaging of the layers of abdomen wall in the left flank of laparotomy in large ruminant such as dairy cows was reported (Braun et al., 2011; Buczinski et al., 2010; Buczinski et al., 2012). However, there was no report on ultrasonography imaging in the layers of muscle of the abdomen wall in the small ruminant. This study was designed to image ultrasonographically the layers of muscle of left flank in the abdomen wall of Ettawah grade goat in Indonesia. Through this study, the basic data on anatomy would be collected that could be used as a scientific consideration for veterinarian to conduct laparotomy surgical procedure to help and aid difficulty in parturition or kidding in Ettawah grade does.

\section{MATERIALS AND METHODS}

\section{Experimental Animals}

Eleven mature (approximately 1.5 years old and had at least 1 time lambing) female Ettawah grade does were used in this study. The experimental does were obtained from the Ettawah grade goat farmers in the Bogor area, West Java. The experimental does were several months mated naturally previously with Ettawah grade bucks by the farmer. The experimental does were then grouped according to the status and age of pregnancy based on the results of ultrasonography diagnose.

\section{Diagnose of Pregnancy by Ultrasonography Imaging}

Ultrasound diagnose of the status and age of pregnancy was conducted trans-rectally (Amrozi \& Setiawan, 2011; Santoso et al., 2014). Brightness-mode trans-rectal ultrasonography imaging was conducted by using SonoDop A-4 ultrasound console (PT Karindo Alkestron, Indonesia). Linear transducer with frequency of $5.0 \mathrm{MHz}$ was used in this procedure. The transducer was added with modified special tool by using plastic handle 30-40 $\mathrm{cm}$ and then added ultrasonic gel to facilitate the insertion of transducer into the rectum. The pregnancy status was diagnosed directly from the ultrasound examination and the image was documented and saved in the format of JPEG.

\section{Ultrasonography Imaging of Left Flank of Laparotomy Incision Site}

The experimental does were handled and restrained without anesthesia on the standing position. Brightnessmode ultrasonography imaging of left flank of laparotomy incision site was conducted trans-cutaneously by using the same ultrasonography and transducer. The hairs in the skin of the laparotomy incision site at the left flank of the abdomen around $5 \mathrm{~cm}$ from tuber coxae were shaved around $2 \times 10 \mathrm{~cm}^{2}$ vertically. Ultrasound gel was applied in the skin surface to gain a better sonographic image. The sonogram of abdominal wall layers from skin until peritoneum was observed and identified layer by layer. The thickness of tissue in each layer was measured and analyzed statistically to know the difference among them. Ultrasound image of abdomen wall layers of the left flank laparotomy site was then documented and saved in the JPEG format.

\section{Data Analysis}

The collected and obtained data were then analyzed statistically by using SPSS v.16.0 (SPSS Inc., Chicago, IL) with Oneway-ANOVA post hoc Duncan test to know the difference between groups with the level of significance $P<0.05$. Data were presented in the mean $\pm S D$ and were narrated descriptively.

\section{RESULTS AND DISCUSSION}

Figure 1 shows the ultrasound image of pregnancy status transrectally and the muscle layers of the incision site at the left flank abdomen transabdominally of the Ettawah grade does. The age of pregnancy was imaged by the presence of fetus and the changes occurred in the reproductive organ tissue (Figure 1B1-3). The ultrasound image of uterus organ (Ut) in the non-pregnant Ettawah grade does appeared without a clear lumen with the presence of active ovary (Ov). However, in pregnant Ettawah grade does, it was clearly seen the fetal sac (Gs) as an indication of pregnancy with the age of less than 1 month, uterine lumen (L) and cotyledon (Cot) as an indication of pregnancy with the age of more than 1 month.

Further, the ultrasound image of the muscle layers were consisted of skin layer (s), subcutaneous layer (sc), oblique external abdominal muscle (Ab.ext), oblique internal abdominal muscle (Ab.int), transversal abdominal muscle (Ab.trn) and peritoneum (p) which changed and different among ages of pregnancy (Figure 1C1-3). Ultrasound image of abdominal wall of left flank of laparotomy incision site in the Ettawah grade does was similar to that of dairy cows (Buczinski et al., 2010). Ultrasound image of soft tissue such as skin and muscles were shown as gray color (hypoechoic), but the harder tissue such as muscle fascia and peritoneum appeared more white (hyperechoic) (Noviana et al., 2012).

Table 1 shows the pregnancy status by trans-rectal ultrasound examination in 11 Ettawah grade does. Around 55\% (6 out of 11) of Ettawah grade does were diagnosed non-pregnant and 45\% (5 out of 11) were pregnant. Among the pregnant does $60 \%$ (3 out of 5 ) with the age of pregnancy $<1$ month (early pregnancy) and $40 \%$ ( 2 out of 5 ) with the age of pregnancy $>1$ month (middle to late pregnancy). Based on the ultrasound diagnose, the Ettawah grade does were then grouped into 3 groups i.e., non-pregnant does $(n=6)$, pregnant does with the age of pregnancy $<1$ month $(n=3)$ and pregnant does with the age of pregnancy $>1$ month $(n=2)$.

The ultrasound image analysis of thickness of abdomen wall in the left flank of laparotomy incision site showed that there was no difference among the groups (Table 2). However, the status of pregnancy with the age 
of pregnancy $<1$ month and $>1$ month were significantly affected the thickness of oblique external abdominal muscle (Ab.ext) and oblique internal abdominal muscle (Ab.int). In pregnant does, both the muscle layers were thicker as compared to those in non-pregnant does $(\mathrm{P}<0.05)$.

The status of pregnancy physiologically affects the structure of abdominal muscles due to the presence of
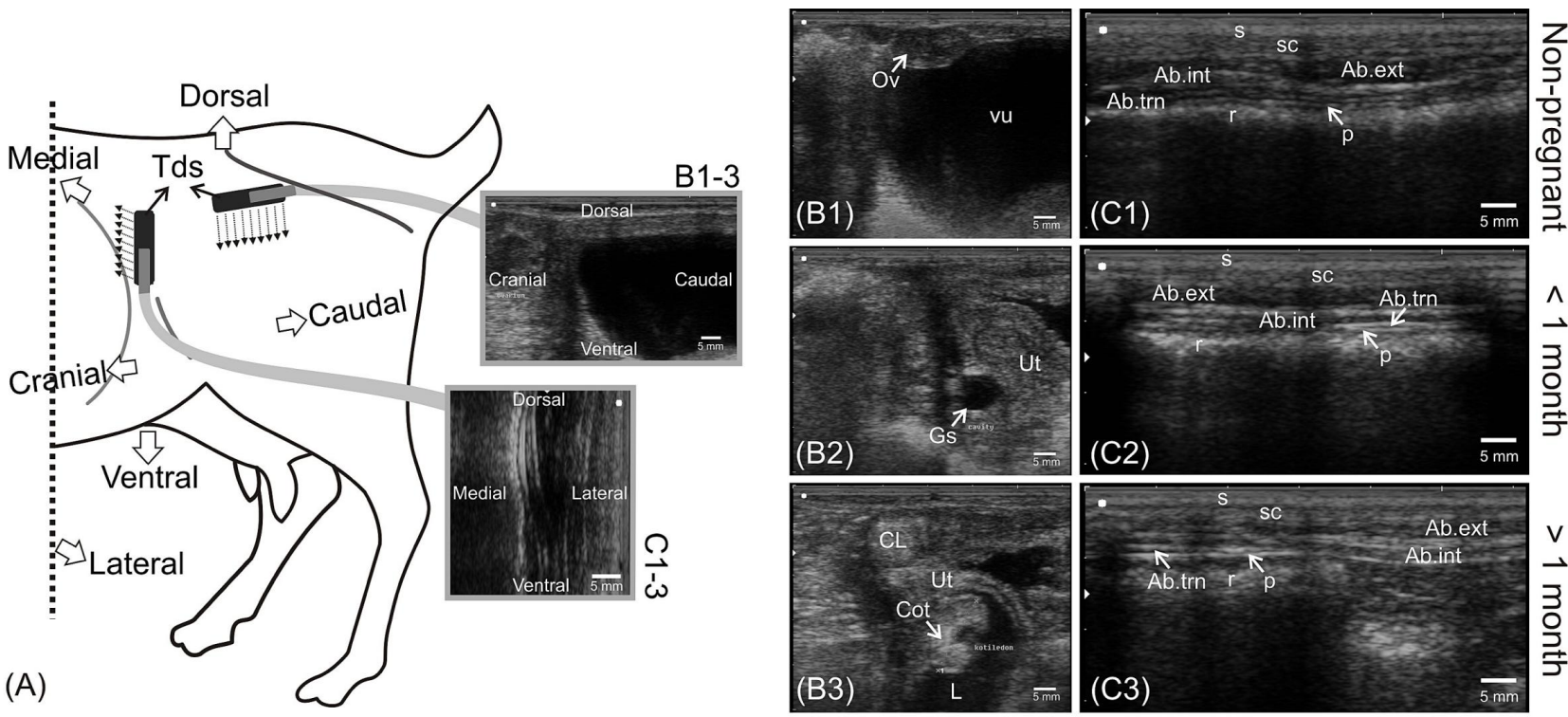

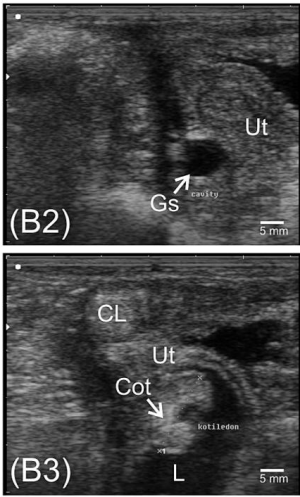

Pregnancy

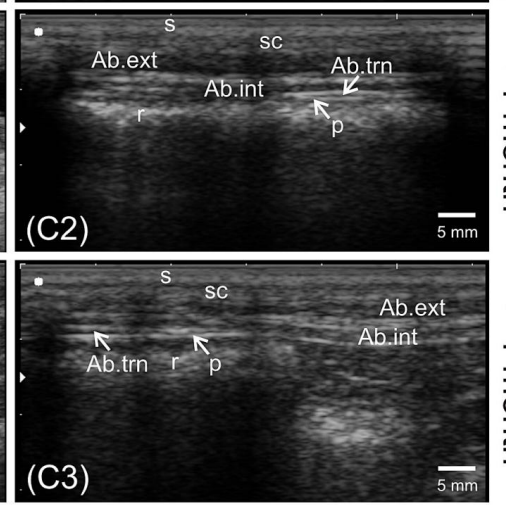

Layers of muscle abdominal

Figure 1. Ultrasound diagnosis of pregnancy and the muscle layers of abdominal wall at the left flank of laparotomy incision site in Ettawah grade does. (A) Imaging technique for diagnosis of pregnancy and flank of laparotomy incision site; Tds= transducer; vertical incontinuous line= imaginer of midline of the body; incontinuous arrow= direction of ultrasound wave. (B1-3) Ultrasound image of pregnancy; $\mathrm{Ov}=$ ovary; $\mathrm{vu}=$ vesica urinary; $\mathrm{Ut}=$ uterus; $\mathrm{Gs}=$ gestational (fetal) sac; $\mathrm{CL}=\mathrm{corpus}$ luteum; Cot= cotyledon; L= lumen. (C1-3) Ultrasound image of thickness profile of muscle tissues of the left flank of laparotomy incision site; $\mathrm{s}=\mathrm{skin} ; \mathrm{sc}=$ subcutaneous tissue; $\mathrm{Ab}$.ext= oblique external abdominal muscle; $\mathrm{Ab}$.int= oblique internal abdominal muscle; $\mathrm{Ab} \cdot \mathrm{trn}=$ transversal abdominal muscle; $\mathrm{r}=$ rumen; $\mathrm{p}=$ peritoneum.

Table 1. The result of pregnancy diagnosis by ultrasonography in 11 Ettawah grade does

\begin{tabular}{|c|c|c|c|c|}
\hline No & The status and age of pregnancy & Pregnancy profile & $\begin{array}{c}\text { Number } \\
\text { (head) }\end{array}$ & $\begin{array}{c}\text { Percentage } \\
(\%)\end{array}$ \\
\hline 1 & Non-pregnant & $\begin{array}{l}\text { The uterus was empty from embryo or fetus, the active } \\
\text { ovaries with follicles, vesica urinary was filled by urine }\end{array}$ & 6 & $6 / 11(55)$ \\
\hline 2 & $\begin{array}{l}\text { Pregnant with }<1 \text { month of } \\
\text { pregnancy }\end{array}$ & $\begin{array}{l}\text { The embryo was attached to the uterine wall (endometri- } \\
\text { um), embryonal and fetal sac were still small in size }\end{array}$ & 3 & $3 / 11(27)$ \\
\hline \multirow[t]{2}{*}{3} & $\begin{array}{l}\text { Pregnant with }>1 \text { month of } \\
\text { pregnancy }\end{array}$ & Cotyledon, placenta and very large fetal sac was observed & 2 & 2/11 (18) \\
\hline & & Total & 11 & $11 / 11(100)$ \\
\hline
\end{tabular}

Table 2. Morphometry of muscle layers of abdominal wall at the left flank of laparotomy incision site in Ettawah grade does

\begin{tabular}{|c|c|c|c|c|c|}
\hline \multirow[b]{2}{*}{ No } & \multirow{2}{*}{$\begin{array}{l}\text { Left flank of laparotomy } \\
\text { incision site }\end{array}$} & \multicolumn{3}{|c|}{ Thickness of tissue (mm) } & \multirow[b]{2}{*}{$P$ value } \\
\hline & & $\begin{array}{c}\text { Non-pregnant } \\
(\mathrm{n}=6)\end{array}$ & $\begin{array}{l}\text { Pregnant with }<1 \text { month } \\
\quad \text { of pregnancy }(n=3)\end{array}$ & $\begin{array}{l}\text { Pregnant with }>1 \text { month } \\
\text { of pregnancy }(n=2)\end{array}$ & \\
\hline 1 & Ab.wall & $13.7 \pm 0.6^{\mathrm{a}}$ & $14.1 \pm 0.6^{\mathrm{a}}$ & $14.0 \pm 0.2^{\mathrm{a}}$ & 0.619 \\
\hline 2 & $\mathrm{~S}+\mathrm{Sc}$ & $7.2 \pm 0.8^{\mathrm{a}}$ & $6.5 \pm 0.3^{\mathrm{a}}$ & $6.0 \pm 0.2^{\mathrm{a}}$ & 0.106 \\
\hline 3 & Ab.ext & $2.0 \pm 0.2^{\mathrm{a}}$ & $2.5 \pm 0.5^{b}$ & $2.8 \pm 0.1^{b}$ & 0.008 \\
\hline 4 & Ab.int & $1.9 \pm 0.2^{\mathrm{a}}$ & $2.5 \pm 0.0^{\mathrm{b}}$ & $2.4 \pm 0.1^{b}$ & 0.003 \\
\hline 5 & Ab.trn & $1.9 \pm 0.5^{\mathrm{a}}$ & $1.9 \pm 0.4^{\mathrm{a}}$ & $2.2 \pm 0.1^{\mathrm{a}}$ & 0.587 \\
\hline 6 & $\mathrm{P}$ & $0.8 \pm 0.2^{\mathrm{a}}$ & $0.8 \pm 0.3^{\mathrm{a}}$ & $0.7 \pm 0.0^{\mathrm{a}}$ & 0.747 \\
\hline
\end{tabular}

Note: Ab.wall= abdominal wall, $\mathrm{S}=$ skin, $\mathrm{Sc}=$ subcutaneous tissue, Ab.ext= oblique external abdominal muscle, Ab.int $=$ oblique internal abdominal muscle, Ab.trn = transversal abdominal muscle, and $\mathrm{P}=$ peritoneum. Data were presented in mean and standard deviation (mean $\pm \mathrm{SD})$. Means in the same row with different superscripts differ significantly $(\mathrm{P}<0.05)$. 
developing of fetus inside the uterus. The abdominal muscles adapted physiologically to accommodate the increasing load caused by the advance of pregnancy. The volume of muscle increases continuously in order to accommodate the increased fetus (Gilleard \& Brown, 1996). Study of abdomen muscle in pregnant women by using Magnetic Resonance Image (MRI) also shows a similar result that both of the oblique external and oblique internal abdominal muscles increases the size with the advance of pregnancy (Hides et al., 2006).

\section{CONCLUSION}

The muscle layers of abdomen wall at the left flank of laparotomy incision site in Ettawah grade does could be very well differentiated by ultrasound imaging. The status of pregnancy and the age of pregnancy in Ettawah grade does affect the thickness of oblique internal and oblique external abdominal muscles.

\section{ACKNOWLEDGEMENT}

The authors express deep appreciation to Dr Drh Boky Jeanne Tuasikal, MSi from Pusat Aplikasi Teknologi Isotop dan Radiasi (PATIR) - BATAN and Bangun Karso Farm for their cooperation in the use of goats in this study.

\section{REFERENCES}

Amrozi, \& B. Setiawan. 2011. Sinkronisasi estrus dan pengamatan ultrasonografi pemeriksaan kebuntingan dini pada domba garut (Ovis aries) sebagai standar penentuan umur kebuntingan. Jurnal Kedokteran Hewan 5:73-77.

Bedard, S., A. Desrochers, G. Fecteau, \& R. Higgins. 2001. [Comparison of four protocols for preoperative preparation in cattle]. Can Vet J. 42:199-203.

Bienek, A., \& E. Grunert. 1997. Sonographic control of wound healing after caesarean section in cattle. Dtsch Tierarztl Wochenschr. 104:423-427.

Bourel, C., S. Buczinski, A. Desrochers, \& D. Harvey. 2013. Comparison of two surgical site protocols for cattle in a field setting. Vet Surg. 42:223-228. http://dx.doi.org/10.1111/ j.1532-950X.2013.01089.x

Braun, U., U. Gorber, M. Hassig, \& K. Nuss. 2011. Ultrasonography of the abdominal wall before and after laparotomy in cows. Schweiz Arch Tierheilkd. 153:71-77. http://dx.doi. org/10.1024/0036-7281/a000153
Buczinski, S., C. Bourel, \& A. M. Belanger. 2010. Ultrasonographic determination of body wall thickness at standing left laparotomy site in dairy cows. Vet. Rec. 166:204-205. http://dx.doi.org/10.1136/vr.b4777

Buczinski, S., C. Bourel, \& A. M. Belanger. 2012. Ultrasonographic assessment of standing laparotomy wound healing in dairy cows. Res. Vet. Sci. 93:478-483. http://dx.doi. org/10.1016/j.rvsc.2011.07.028

Gilleard, W. L., \& J. M. Brown. 1996. Structure and function of the abdominal muscles in primigravid subjects during pregnancy and the immediate postbirth period. Phys. Ther. 76:750-762.

Hides, J., S. Wilson, W. Stanton, S. McMahon, H. Keto, K. McMahon, M. Bryant, \& C. Richardson. 2006. An MRI investigation into the function of the transversus abdominis muscle during "Drawing-In" of the abdominal wall. Spine (Phila Pa 1976). 31:E175-E178. http://dx.doi.org/10.1097/01. brs.0000202740.86338.df

Mann, F. A., G. M. Constantinescu, \& H. Y. Yoon. 2011. Fundamentals of small animal surgery. John Wiley \& Sons, UK. p. 3-406.

Mee, J. F. 2008. Prevalence and risk factors for dystocia in dairy cattle: A review. Vet. J. 176:93-101. http://dx.doi. org/10.1016/j.tvjl.2007.12.032

Noviana, D., S. H. Aliambar, M. F. Ulum, \& R. Siswandi. 2012. Small animal diagnostic ultrasound [Diagnosis ultrasonografi pada hewan kecil]. IPB Press, Bogor. pp. 3-8.

Novita, C. I., A. Sudono, I. K. Sutama, \& T. Toharmat. 2006. Produktivitas kambing peranakan etawah yang diberi ransum berbasis jerami padi fermentasi. Med. Pet. 29:96-106.

Santoso, S., Amrozi, \& H. Herdis. 2014. Gambaran ultrasonografi ovarium kambing kacang yang disinkronisasi dengan hormon prostaglandin $\mathrm{f} 2$ alfa (PGF2 $\alpha$ ) dosis tunggal. Jurnal Kedokteran Hewan 8:38-42.

Seger, T., E. Grunert, \& D. Ahlers. 1994. The cause of complications of abdominal incision healing after cesarean section in cattle. Dtsch Tierarztl Wochenschr. 101:309-311.

Sukendar, A., M. Duldjaman, \& A. Sukmawati. 2005. Potensi reproduksi dan distribusi dalam pengembangan kambing PE di Desa Hegarmanah Kecamatan Cicantayan Kabupaten Sukabumi Jawa Barat. Med. Pet. 28:1-7.

Tenhagen, B.-A., A. Helmbold, \& W. Heuwieser. 2007. Effect of various degrees of dystocia in dairy cattle on calf viability, milk production, fertility and culling. J. Vet. Med. A. 54:98102. http://dx.doi.org/10.1111/j.1439-0442.2007.00850.x

Wehrend, A., E. Hofmann, K. Failing, \& H. Bostedt. 2006. Behaviour during the first stage of labour in cattle: Influence of parity and dystocia. Appl. Anim. Behav. Sci. 100:164-70. http://dx.doi.org/10.1016/j.applanim.2005.11.008 